\title{
The Missing Link: Studying Political Leadership from the Followers' Perspective
}

Rudolf Metz

Centre for Social Sciences, Hungary

Corvinus University of Budapest, Hungary

Recent political developments suggest that political followership has played increasingly vital roles in modern democratic politics. However, scholarship seemingly lacks proper conceptual and methodological tools for analysing why and how citizens follow their leaders, and what the role of this relationship is in personalised politics and political leadership. Addressing the research gap, this article turns to generic leadership studies for help, and introduces its follower-centric models into the field of political science. This venture opens with a review and comparison of some of the different perspectives about political followers in the scholarship on political leadership and personalisation, taking account of their limitations. It then moves on to assess followercentric models and their empirical results, focusing on observers' perceptions about the characteristics and behaviours of leaders in the attribution of leadership. Based on these models, the article offers a balanced perspective about leader-followers relations. Recommendations for future research directions are presented in the concluding sections.

Keywords

political leadership, followers, personalisation, follower-centric leadership models, followership

One cannot have leaders without followers, but going further, one cannot understand leadership without understanding followership.

(Fiorina and Shepsle, 1989: 36 Italics in the original)

In recent years, the call for more follower-centric research has constantly grown louder among students of political leadership (Blondel, 2014: 711-712; Hartley, 2018: 209-210; Kellerman, 2008; Metz, 2021) and personalisation (Garzia, 2011), in line with the strengthening trend in the generic leadership literature (Uhl-Bien et al., 2014). Within this scholarship, leadership researchers describe leadership as a social construct induced by followers' cognitive-, attribution-, and identification processes. This subjectivist approach does not preclude analysing the leader-follower relationship through scientific methods. Moreover, it offers standardised and reliable measurement tools that political scientists can use to understand the role of followers and followership in personalised politics. The article addresses this research gap by introducing follower-centric models of generic leadership studies (Shamir, 2009) into the field of political science.

The growing interest of political scientists in this area is not surprising. Current events, such as the electoral victory and defeat of Donald Trump, the Brexit referendum and subsequent British parliamentary elections, and the rise of and reactions to populist politicians, show that politics has become a more hectic activity in modern democracies. Fierce and antagonistic emotions are reflected primarily in the transformation of citizens' relationships with their leaders. Public trust in the political elite has vanished or become more volatile; citizens have become more cynical and critical of political leadership; while the 'cult of strong leaders' has also strengthened (Foa and Mounk, 2016). Moreover, people formulate often contradictory (Medvic, 2013) or unrealistic expectations (Flinders, 2012) 
towards leaders, and their perceptions of leadership achievements are also biased by social and political ties (Achen and Bartels, 2016; Flinders, 2012). Although these tendencies draw attention to the importance of political followership and leader-follower relations, political science struggles to interpret - and so generally ignores - these dynamics.

In this regard, the diagnosis formulated by James McGregor Burns (1978: 3) still seems to be valid: namely, that understanding the process of political leadership and leadership relationships is made overly difficult by two biases: 'normativism' and 'leader-centrism'. Mainstream political science generally concentrates on public opinion, voters, and citizens, or on collective actors (political parties or movements and representative institutions). Implicitly or explicitly, these studies share an antielitist belief that leaders act as citizens' obedient agents, which limits the role of leadership. Due to this normative bias, the term 'follower' or 'followership' is associated with negative and passive connotations when compared to ideas like 'voters', 'voting', 'citizens', and 'citizenship', which prescribe active political participation (Barber, 2000). However, the literature on personalisation has recognised that attitudes towards leaders can potentially influence voting behaviour (leader effects: Garzia, 2011; Lobo, 2014), inflate job approval ratings (Greene, 2001; Newman, 2003), and affect the formation of policy preferences (leader cue: Agadjanian, 2020; Lenz, 2012). Despite this, scientific interest and empirical research on this topic still lags far behind that dedicated to parties, policy issues, and ideologies (cf. Garzia, 2011; Lobo, 2014).

The opposite pole of political science also falls short of satisfying this research interest. Political leadership studies recognised that leadership is more complex than the over-romanticised idea of strong leaders (Brown, 2014) accepting the dark side (Helms, 2012) and collective (Campus et al., 2021) and distributed forms of political leadership (Elgie, 2011; Kane et al., 2009). Still, researchers are determined strongly by leader-centrism and as Burns (1978: 1) stated: '[i]f we know all too much about our leaders, we know far too little about leadership' (Italics in the original). They have overemphasised the role of formal power-holders and their traits and institutional and political resources in the leadership process (e.g. Bennister et al., 2017; Elgie, 1995; Helms, 2005) giving limited and insignificant role for followers.

In fact, beyond the commonplace that there is no leadership without followership, followers play a critical role in politics. Generally speaking, followership refers to the relationship between leaders and their followers that determines leadership and the behaviour of participants. This relationship is based on the fact that followers are attracted to their leaders because of the latter's appreciated (perceived or actual) qualities. Belief and trust in leaders determine followers' behaviour: the latter accept political messages and are influenced; they recognise, empower, and elect leaders. However, they can also limit or control them under certain circumstances (oppositional mobilisation, resistance, or changing expectations). Phrased differently, followership undoubtedly does not solely involve passive/reactive spectatorship and obedience. It is 'voluntary' or even proactive action in the absence of coercion (but not necessarily without manipulation) based on the sole reason that people believe it is a right and/or necessary thing to do. In this sense, electoral mobilisation, changes in preferences, and the actions of followers that the latter feel obligated to undertake as their leaders would expect such, are the outcomes of leader-follower relations.

This paper argues that studying political followership through follower-centric models of generic leadership studies (Shamir, 2009) is essential for obtaining a much clearer picture about why and how followers relate to their leaders, and what the role of followership is in personalised politics and political leadership. In this light, the article aims to contribute to the two strands of literature. 
Follower-centric models can extend existing political cognition and personality theories (e.g. Caprara and Zimbardo, 2004; Kinder et al., 1980) by unfolding the relationship between leader-followers in personalised politics. Studying political followers and followership also enriches our knowledge of political leadership in general. Placing the leader-follower relationship at the centre of the inquiry does not substitute for examining leaders and their formal/informal activities. However, it enables us to form a more balanced perspective about political leadership.

The structure of the study is as follows. First, the article discusses the limited perspective of political leadership studies concerning the role of followers in the leadership process. Second, I review research on personalised politics that has touched on some dimensions of the leader-follower relationship, pointing out their conceptual limitations. Third, I conceptualise the relationship in terms of follower-centric models and the politically relevant empirical results of generic leadership studies. Finally, lessons and implications for future studies are discussed.

\section{A Blind Spot in Political Leadership Studies: Followership}

It is no coincidence that we first address political leadership studies in relation to political followers. According to the dominant interactionist paradigm (Elgie, 2015: 21) in the research, leadership refers to a particular relationship between leaders and followers in a specific social and institutional setting. Put differently, leaders always act in a group context, aiming to convince others to follow.

An excellent example of this paradigm is Burns' (1978) leadership theory. In his seminal book, leadership styles (transformative and transactional leadership) are distinguished by the quality and nature of the power relationship between leaders and followers. Although Burns did not delve into the behaviour of followers, his students did. Kellerman (2008) and Nye (2008) seek to capture the behaviour and position of followers in the leadership process, focusing on 'good' (critical, independent, and proactive) followership. Their typologies take into account followers' engagement and their (positive/negative) attitudes toward their leaders (Kellerman classifies the former as 'isolates', 'bystanders', 'participants', 'activists', and 'diehards') or their loyalty and independent thinking (Nye: 'alienated', 'empowered', 'passive', and 'conformist' followers). They clearly raise researchers' awareness for the problem of followership and push forward its conceptualisation as they define followers' role in leadership as agents of possible change. Nonetheless, these works have not generated further empirical applications due to their application of a strong normative approach that involves differentiating between good and bad followers.

The vast majority of research still focuses on the institutional constellation and outcomes of leadership and leaders' formal positions and resources. This institutional/positional approach describes a linear leadership process in which followership is defined as resources or moderators (e.g. popularity, societal attitudes, popular desires, established commitments) that support or limit the leader's political power and capital (e.g. Bennister et al., 2017; Elgie, 1995; Skowronek, 1997) (Fig. 1). Probably Bennister and his colleagues' (2017) Leadership Capital Index model has gone furthest in terms of conceptualising and operationalising the leadership relationship. The authors integrate the relational capital (i.e. the popularity of the leader's party, the chance of being replaced, and public trust in the leader) as an analytical dimension (alongside leaders' skills and reputation) that leaders gain from the support of the electorate and their party.

The main problem with this approach is that scholars focus primarily on leaders' decisions, behaviour, and the changes they cause, avoiding questions about how leaders influence directly and indirectly their followers, how followers can control the leadership process, and what the consequences are of 
the leadership process for them. All in all, despite some refreshing exceptions (Campus et al., 2021; Elgie, 2011; Kane et al., 2009) political leadership studies remain overly leader-centric, and lack empirical research on political followers is notable.

Figure 1 Relationship between leaders and followers according to the institutional/positional approach of political leadership studies

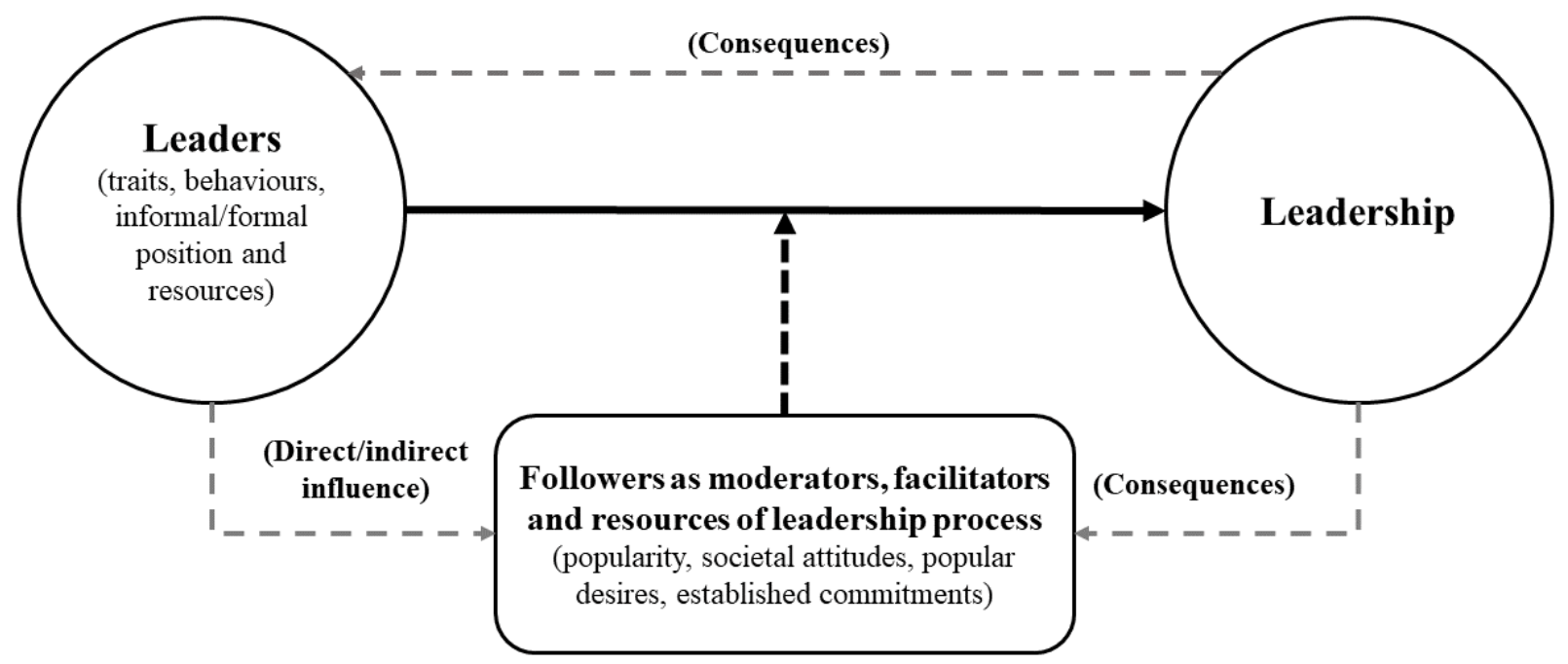

\section{Followers and Followership in Personalised Politics}

In mainstream political science, researchers also avoid - as far as this is possible - the concept of followers and the phenomenon of followership, but for different reasons. They usually consider any disjunction between leaders and followers to be incompatible with democratic politics (Barber, 2000), in contrast to the idea of voters and citizens, who represent one of the cornerstones of liberal democracy: active and rational participation. From this highly normative point of view, the process of personalisation appears to be a negative development 'in which the political weight of the individual actor in the political process increases over time, while the centrality of the political group (i.e., political party) declines' (Rahat and Sheafer, 2007: 65; see also: Karvonen, 2010: 4). Numerous factors, including eroding social cleavages, weakening party identification, strengthening mediatisation, and declining political parties and parliaments, contribute to the growing importance of personalities in politics (McAllister, 2007; cf. Karvonen, 2010). Critics argue that personalisation reinforces citizens' irrationality and hunger for and dependence on charismatic and populist appeals, undermining democratic accountability. Moreover, some interpret personalisation as part of a broader process (presidentialization: Poguntke and Webb, 2018) in which leaders became more and more dominant in democracies by relying on their increasing leadership-based power resources and autonomy within government and parties.

Nevertheless, theories of personalised politics are built implicitly on the process of political leadership and followership (see: Barisione, 2009b; Garzia, 2011), as they direct our attention to personal and direct relationships that bond politicians to ordinary citizens (Fig. 2). This relationship is twofold (Caprara and Zimbardo, 2004). First, politicians seek to capture the centre stage of politics conveying a favourable personal image. Second, citizens' and politicians' personalities, traits, and values became crucial in translating preferences into actual decisions. However, the vast majority of the literature deals not with this relationship, but its outcomes: the leader's effects on citizens' vote choice, leader's job approval ratings, and policy preferences.

Figure 2 Relationship between leaders and followers in personalised politics 


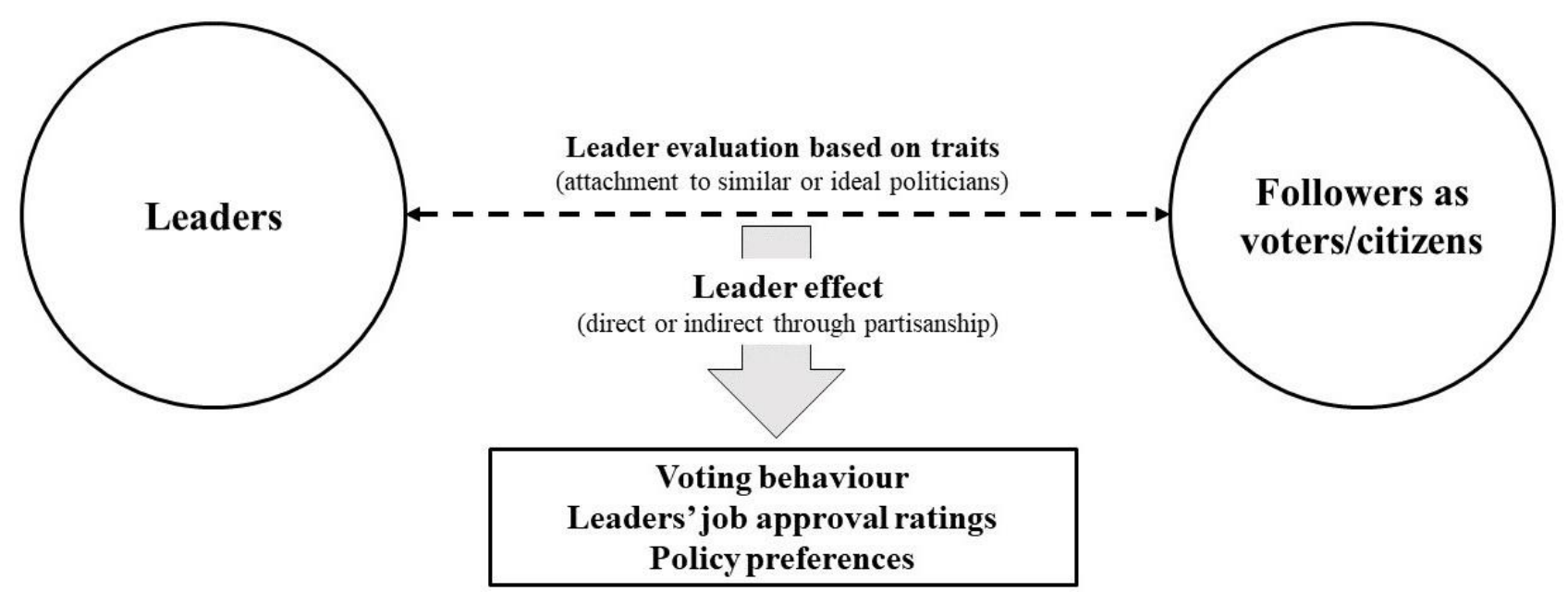

Source: partly adapted from Garzia, 2011: 707

Regarding voting behaviour, Barisione (2009a: 474) sees the 'leader effect' as the 'added value, in electoral terms, that a specific national candidate is able to bring his/her party or coalition through the effectiveness of his/her public image as appraised at that specific time'. However, researchers are far from unanimous about whether leaders have a real impact on voters since the former's results depend on what countries (political systems) and time periods they examine and what methodology they apply. Some researchers (Aarts et al., 2011; King, 2002) reach the sceptical conclusion that leader evaluation is not an important factor in voting patterns. In contrast, many studies (Bittner, 2011; Garzia et al., 2020; Lobo and Curtice, 2015) have found that leaders do matter for voter choice when the latter phenomenon is appraised with an appropriate research design and conceptualisation. A more complex relationship is recognised behind this effect - i.e., that leaders can influence individuals indirectly through party identification (Garzia, 2013; Page and Jones, 1979). Moreover, the leader effect also works in the opposite direction. Negative feelings toward opposing leaders anticipate voting behaviour, thereby strengthening affective polarisation (Druckman and Levendusky, 2019; Garzia and da Silva, 2021).

The influence of leaders is reflected not only in voters' behaviour but also in approval and support for the heads of the executive branch. Although some studies focus on how the public assessment of executive leaders affects performance ratings (see, for example, Greene, 2001; Newman, 2003 about the presidents of the U.S.), most explanations have become stuck on the level of macro factors, such as governance outcomes (e.g. economic performance), major domestic and international events (e.g. terrorist attacks, wars and pandemics), and institutional context. Nevertheless, studies of the 'rallyround-the-flag effect' (Baker and Oneal, 2001; Mueller, 1970) have recognised critical leaderfollower dynamics in times of crisis, when popular support for an incumbent leader suddenly leapfrogged. This effect is typically short-lived and does not extend to party preference. The phenomenon may appear to be similar in different circumstances (e.g. concerning the country-specific context, crisis severity, crisis management strategy, and elite cooperation) but also different in similar circumstances (e.g. the approval ratings of executive leaders during the coronavirus epidemic). This reveals that this relationship may be determined mainly by personal factors (Bligh et al., 2004).

Another stream of research draws attention to the complex relationship between leaders and followers' policy preferences, or so-called 'follow-the-leader' behaviour. The latter has found that leader cues - political actors' position-taking on a policy issue - significantly impact public opinion, resulting in changes in voter preferences. Lenz (2012) demonstrated in Follow the Leader? that people first choose which political leader they want to support, and then adopt their political views, 
rather than the other way around. In short, people modify their opinions to match their leaders' preferences. Although Lenz's research explicitly built on the classic paradigm of electoral research (Campbell et al., 1960), subsequent results questioned the centrality of partisanship and underlined the direct impact of leaders on policy preferences. Empirical evidence provided by a series of studies (Agadjanian, 2020; Barber and Pope, 2019; Broockman and Butler, 2017) has proved that citizens tend to still support their leaders even if the latter take public policy positions supported by rival parties or opposed by their own parties.

Besides recognising the vivid and vital relations of the actors, the literature has provided little explanation of why and how citizens follow their leaders in personalised politics (Garzia, 2011: 706). Empirical research in political cognition found that leaders' personality traits play a crucial role in organising information and evaluating candidates (Kinder, 1986; Kinder et al., 1980; Miller et al., 1986; Rahn et al., 1990; Sullivan et al., 1990). Leaders' personality traits are used as cognitive shortcuts or heuristics by voters to anticipate and assess politicians' future decisions, actions, and performance during their term in office.

These studies differentiate two modes of relationships. Citizens can define "superhuman" or idealistic standards (e.g. Kinder et al., 1980; Sullivan et al., 1990), expecting their leaders to prove their exceptional abilities that distinguish them from others; or "everyman" standards (e.g. Caprara and Zimbardo, 2004; Sullivan et al., 1990), expecting leaders to represent them through their similar character. In short, citizens judge whether politicians meet their personal normative and abstract expectations. Caprara and Zimbardo's (2004) empirical model of leader-voter congruency expanded the similarity-attraction thesis. According to this model, voters seek and support politicians whose personality matches their own. The former note that:

'We want to trust competent leaders, but we also want to like them personally, and this is easier when they are perceived as essentially similar to us. The extent to which voters perceive their leaders' personalities as similar to their own is critical in humanising abstract icons and endorsing politicians' efforts and claims.' (Caprara and Zimbardo, 2004: 590)

However, as the latter underlines, successful politicians need to understand the 'language of personality' to convey their constituents' characteristics in a specific place and time. Similarly, Barisione (2009b) argues in his theoretical work that leaders can form their valence image (set of traits) to win recognition from potential followers regardless of whether they want to stand out from or to emphasise similarity to their community.

Although findings (Miller et al., 1986) support the assumptions of personalised politics that leaders' characters have a long-term effect on voting behaviour, thereby calling into question the classical paradigm (Campbell et al., 1960), these models are not able to fully describe the relationship between leaders and followers. Studies lack a unified theoretical framework that would justify the choice of what traits or trait dimensions should be considered crucial. As a result, such work examines different trait dimensions, including countless traits (e.g. agreeableness, charisma, competence, empathy, extraversion, integrity, leadership, morality, openness, trustworthiness, warmth, etc.). Moreover, since politicians' traits tend to remain stable throughout the years (Caprara and Zimbardo, 2004; Miller et al., 1986), this approach cannot be applied to interpret the dynamic nature of such relationships and potential changes thereof. It is also problematic that the former focuses on leaders' personalities and characters, not on the attribution of leadership. Although leadership or charisma appear among personality traits, they are often lost among them (for instance, when leadership is 
integrated into the dimension of competence). This also involves identifying leadership of a particular style (e.g. strong, commanding and inspiring leadership). At this point, it is worth calling on followercentric models to increase understanding.

\section{Follower-centric Models of Generic Leadership Studies}

Follower-centric models of generic leadership research (Shamir, 2009) could help us widen our perspective about leadership process and relationships. These theories describe leadership as a social construct induced by followers' cognitive-, attribution-, and identification processes. Followers' beliefs about leaders' traits, behaviour, and the consequences of leadership are crucial - it is assumed that these processes define the causes of followers' behaviour. We observe political events and actors and try to interpret their underlying sources of motivation and traits. If politicians meet our preconceived cognitive schemas, we consider them leaders and their activities as leadership. Thus, we follow them. These ideas determine not only our reactions but also our future expectations. Theories of political cognition describe leaders' character assessment similarly. These different directions of socio-cognitive psychological research recognise that people structure their knowledge and expectations through abstract schemas and prototypes that build on daily life experiences (Kinder, 1986; Lord and Maher, 1993; Miller et al., 1986; Rahn et al., 1990; Sullivan et al., 1990).

Follower-centric models can expand existing research into political cognition in theoretical and conceptual sense. First, models also explain possible changes related to contextual factors (such as crises) and leaders' manipulation of their appearances. Second, leadership researchers focus on the effects of the attribution process of leadership (e.g. selection, support for leaders, acceptance of their influence, and evaluation of their performance), identifying the factors that can directly contribute to a leader-follower relationship. Following Howell and Shamir's work (2005), we can distinguish between personalised and socialised relationships. Personalised relationships are dominated by the direct attribution of desirable qualities to a leader. The categorisation theory of leadership (Lord et al., 2020; Lord and Maher, 1993) describes this process, examining individuals' universal leadership prototypes or implicit leadership theories. In contrast, a socialised relationship is derived from imaginary or real group membership. The perceived similarity between leaders and followers stems primarily from shared group membership. This attribution process is detailed by the leadership's social identity approach (Haslam et al., 2020; Hogg, 2001; Hogg et al., 2012). Researchers are also aware these processes are not free from distortions. The 'romance of leadership' thesis (Meindl, 1990, 1995; Meindl et al., 1985) indicates that followers have heightened expectations and idealisations about leadership. I now present these models and their relevant empirical results.

\section{Personalised relations: implicit leadership theories}

Judgements about leadership qualities depend heavily on individuals' own implicit leadership theories. According to the leadership categorisation theory of Lord (et al. 2020) and Lord and Maher (1993), people think in cognitive categories (e.g., 'dog') into which similarity-based traits (e.g., 'barking', 'biting', 'furry') are employed to classify experiences of different objects, events, and people. Above a certain level of abstraction, categories are organised into prototypes or implicit theories that generalise the characteristics of each element of the category. Ultimately, prototypes help us to identify explicit examples (e.g., 'the neighbour's dog'). The implicit nature of theories means that these are created by socialisation or previous experience and are often used without awareness and intention. 
What makes a (political) leader? Lord and Maher (1993) envisioned a three-level hierarchical system of leadership categories. The highest level categories involve making a general distinction between leaders and non-leaders. At the middle level, forms of leadership are differentiated according to specific areas (e.g. business, military, or politics). The lowest level categories have additional specifications. For example, our party preferences can determine what characteristics we find important. The emergence of a leadership relationship depends on how well one's experiences fit with these prototypes. To examine these implicit leadership theories, Offermann and Coats (2018) developed a scale with 46 elements that focuses on nine dimensions: sensitivity, dedication, tyranny, charisma, strength, creativity, well-groomed, masculinity, and intelligence. Naturally, this does not mean that an individual must have all these characteristics to be recognised as a leader. Empirical experience also shows that these leadership prototypes are universal - i.e., are independent of cultural, political, and social contexts (Lord et al., 2020).

Previous research has demonstrated that perceptions of political leadership play an important role in voters' preference formation and behaviour. Foti and her co-authors (1982) recognised that implicit leadership theories are also relevant to political candidates. The latter showed that people are able to distinguish an effective political leader from a prototype of political leaders, perceiving them to have different qualities. In other words, there is a strong relationship between trait prototypicality and effectiveness evaluations. Another study (Maurer et al., 1993) confirmed these results, finding that Republican and Democratic voters in the 1988 U.S. presidential elections had different prototypes about effective leadership. Republicans judged effective leaders to be more patriotic, religious, aggressive, tough, and optimistic than Democrats, who were perceived to consider 'humanitarianism' a more important characteristic. Moreover, according to the study, voters' conceptions of effective political leaders was strongly related to voting behaviour.

Another research direction with similar presuppositions focuses on the attribution of charisma to leaders, and has two important lessons for us. First, voters show a natural tendency to identify with the leaders of the parties they support. For instance, from an analysis of the 1992 Israeli elections, Shamir (1994) demonstrated that voters' ideological orientation strongly influenced which candidates they perceived as charismatic. Regarding the 1996 and 2000 U.S. presidential elections, Pillai and Williams' articles (Pillai and Williams, 1998; Pillai et al., 2003) supported Shamir's findings: voters considered their own party's candidates to be significantly more charismatic. However, in some cases (e.g., during a crisis), outsider political challengers could appear to be more charismatic, as researchers (Bligh et al., 2005) showed concerning support for Arnold Schwarzenegger in the 2003 California gubernatorial recall election.

Second, we can also detect a strong correlation between the subjective perception of crisis and the attribution of charisma to a leader. Several studies have examined the impact of the crisis on the emergence of charismatic leadership during, for example, the U.S. presidential elections (Williams et al., 2009, 2012), the 2003 California elections (Bligh et al., 2005), and the 9/11 terrorist attacks (Bligh et al., 2004). Pastor and co-authors (2007) found that high-fear-arousal states produced by crises make followers more susceptible to charismatic influence. These studies show that followers attribute greater charisma and influence to those who are expected to resolve a crisis.

\section{Socialised relations: the social identity approach of leadership}

The process of attribution is determined not only by individual ideals but also by perceived or actual group affiliations. Building on Henri Tajfel's and John Turner's work, the social identity approach of leadership (Haslam et al., 2020; Hogg, 2001; Hogg et al., 2012) interprets this process as not primarily 
an individual but a social/group phenomenon. People cognitively represent social groups through prototypes that denote a mix of complex, obscure interrelated attributes that capture in-group similarities and intergroup differences. When someone says they are 'Austrian' or 'European', this inevitably invokes related mental prototypes about these groups of individuals. We usually also weigh their priority (e.g. "I am primarily Austrian, and only secondarily European", or vice versa). That is, group identification depends on how salient the identity is at the individual and societal levels. However, group prototypicality is also determined by the context in which we compare our group to another ("if I am talking about the United States, I am European", but "if I compare myself to the Germans, I am Austrian”) - despite all apparent similarities. Overall, prototypes are mental constructs that reinforce the fact that groups are seen entitatively rather than as the sum of their members. Emphasising similarities within a group and differences between groups is often referred to as stereotyping and leads to the depersonalisation of others.

A radically contrasting process takes place concerning leaders that political scientists describe as personalisation (which, of course, can also be sustained regarding the individual attribution process). That is, leaders have to demonstrate qualities that a group of potential followers will adore. In this framework, the rise and acceptance of leaders depend on the degree to which the former are prototypical - i.e., how well they represent and embody the core characteristics, aspirations, values, and norms of the group. Thus, leaders can gain more influence if the group's identity becomes salient and a consensus is formed around their prototypicality. This engenders their attractiveness and popularity among group members. However, leaders are not one person, but also the 'best of their group: the 'champions of us'.

A series of empirical studies support the claim that group prototypicality strengthens the acceptance and support of leaders (Platow and van Knippenberg, 2001), trust and perceived effectiveness (Giessner et al., 2009), but also perceived charisma (Steffens et al., 2014). Examining the 2012 Barack Obama and Mitt Romney runoff, Steffens and colleagues (2014) showed that perceived joint group membership and leadership prototypicality resulted in more robust identification, closer personal bonding, and greater charisma. From an examination of the 2008 U.S. presidential elections, research (Alabastro et al., 2013) also pointed out that voters' ideological positions defined who they considered a prototypical leader. Both liberals and conservatives saw themselves as similar to their in-group leader compared to the outgroup leader. However, after the electoral victory, conservative voters recognised their similarities with Barack Obama to a considerable extent as they moved away from supporting the Republican candidate John McCain. Christian (et al. 2018) explained Donald Trump's 2016 electoral victory similarly. The latter's achievements suggest that Republicans saw the former president as more prototypical (embodying party core values) than the Democrats did Hillary Clinton. However, group prototypicality can also have profound consequences in relation to evaluating leaders' performance. Focusing on the German Greens, a survey experiment (Giessner et al., 2009) confirmed that a prototypical leader not only attracts more trust and is seen as more effective, but followers are also more tolerant of them, even after negative outcomes. This result leads us to the issue of perceiving the consequences of leadership.

\section{Idealisation: the romance of leadership}

Followers perceive not only leaders' qualities and activities, but also the results and consequences of their activities. People often attribute the causal mechanism to leadership, but this view of the chain of events can be severely distorted, leading to the over-idealisation of leadership. Meindl's (1990, 1995; et al., 1985) 'romance of leadership' thesis points exactly to this: '[i]t appears that as observers 
of and participants in organisations, we may have developed highly romanticised, heroic views of leadership - what leaders do, what they are able to accomplish, and the general effects they have on our lives' (Meindl et al., 1985: 79). The thesis seeks to capture how people explain various organisational, social, and political events solely through the activities of leaders. Accordingly, people tend to over-attribute collective positive and negative outcomes to leadership, de-emphasising other social or economic factors, thereby overemphasising the role of leaders. This idealisation is a fundamental attributional error (Ross, 1977), but also a psychological need: leadership is an explanatory category that simplifies complex political and social processes.

\section{A Balanced Perspective of Leader-Follower Relationship}

Follower-centric models aim to unfold different dimensions of the leader-followers relationship (Fig. 3). The personal part of the relationship involves the individual attribution process that builds on individuals' mental schemas about universally prototypical leaders. Followers have preconceived ideas about who they are likely to consider a good and effective leader. If perceived reality exceeds, matches, or falls short of this imagination, they may accept someone's offer to lead. The socialised relationship, in contrast, reflects the effects of group membership. Group-specific leadership prototypes condense in-group similarities that politicians ought to embody to be seen as leaders. Overall, these attributional processes determine the selection of and support for leaders, acceptance of their influence, and evaluation of their performance.

Leadership prototypes generated by personalised and socialised relationships embody different ideals (e.g., head of government vs the Austrian chancellor). These ideals can strengthen each other, but sometimes they also involve tensions when political leaders represent a group without meeting the universal expectations of their office, or vice versa. Some circumstances (crisis leadership, coalition governance, or symbolic leadership positions) may reinforce citizens' judgment of their leaders on the basis of a universal prototype, relegating expectations that emerged from group membership to the background. Nor should we forget that the internationalisation of politics has resulted in the growing standardisation of the image of national political leaders, especially in Western democracies (Barisione, 2009b). Otherwise, we can also agree with empirical findings (Alabastro et al., 2013; Christian et al., 2018; Pillai et al., 2003; Pillai and Williams, 1998; Shamir, 1992): that salient group membership (national or political identity) can easily overwrite universal categories (e.g. effective leadership). Moreover, recent trends towards polarisation and populism can also strengthen the components of socialised leadership relations.

The idealisation of leaders and leadership is related to both dimensions of the attribution process. Empirical studies have found a positive correlation between the romance of leadership thesis and charisma attribution (Meindl, 1990; Shamir, 1992; cf. Bligh et al., 2005). A recent study (Carsten et al., 2019) pointed out that those who attributed more influence to leadership saw Donald Trump as more charismatic and effective in the 2016 U.S. presidential elections. Group identification can also strengthen the idealisation of leadership, as empirical results (Giessner et al., 2009) have suggested that group identity (i.e. party affiliation) makes followers more permissive and forgiving of their leaders.

These relations are far from static. Followers' perceptions of leaders' behaviour can easily change due to contextual factors (Bligh et al., 2004) or leaders' actions. Regarding universal prototypes, researchers (Foti et al., 1982; Maurer et al., 1993) have highlighted that leaders seek to emphasise those traits that their followers will probably value to influence voter decision-making. In a socialised 
relationship, leaders can similarly decide which qualities to project to their voters. Moreover, the most successful politicians must become 'identity entrepreneurs' by shaping and manipulating the identities of their followers or deliberately using identity politics (Haslam et al., 2020). Thus this approach does not deny or limit the role of leadership, but merely emphasises that '[i]t is easier to believe in leadership than to prove it' (Meindl, 1990: 161).

\section{Figure 3 Relational trajectories of political leadership}

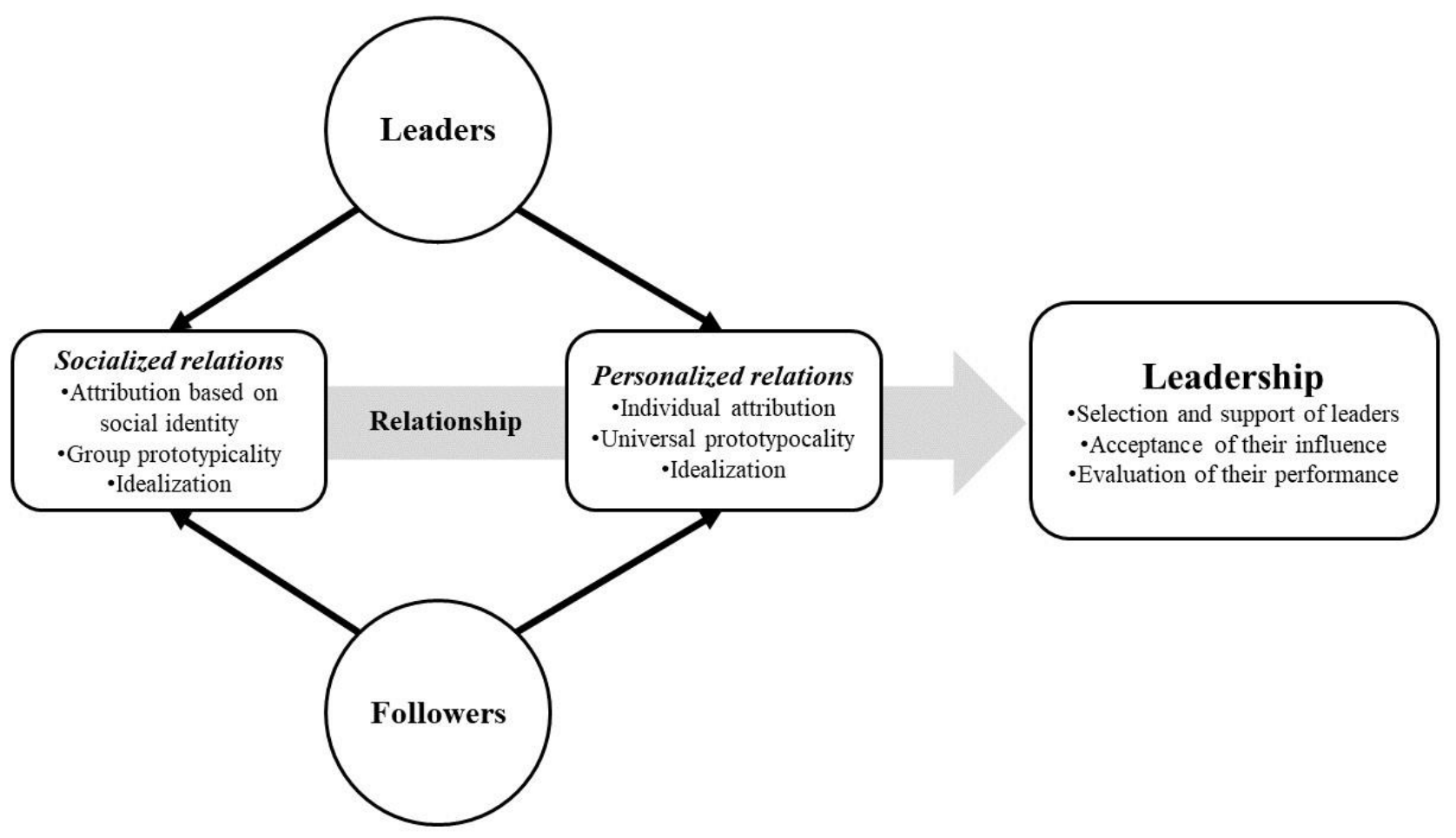

\section{Discussion}

The article argues that the key to understanding leadership and the leader-follower relationship is in the eyes of the beholder. Meindl (et al. 2004: 1348) advised that leadership research should assume that the latter phenomenon operates similarly to the Rorschach test, widely known from psychology. During this test, people are asked to speak associatively about what they see in a series of inkblot pictures. According to Meindl, leaders and their behaviours can be seen as playing a similar role to the inkblot: followers observe and interpret leadership, thereby revealing much about the leadership relationship and the attribution process. For example, in a questionnaire survey participants may be asked to rate leaders, which indeed tells something about the leaders, but may be more revealing about those who do the rating.

The balanced perspective of the leader-followers relationship suggests several areas for future research. As the article has described, political leadership studies can obtain more insight about distant followers (citizens) and their actual impact on the leadership process. We can also apply follower-centric models to analyse the leadership attribution of close followers (i.e. party or cabinet members), an approach that has already generated some scientific interest. For instance, McDonnell (2016), during his analysis of populist leadership, pointed out the varying levels of charisma perceived by members of three radical right-wing parties (although he conceptualised charisma too narrowly). In a similar vein, Gherghina (2021) examined members' perceptions of leadership styles in 12 Bulgarian, Hungarian, and Romanian parties using a modified version of the Multifactor Leadership Questionnaire. However, if researchers do not pay more attention to distant or close 
followership, we cannot explain a core problem of democracy: how followers enable and control representation and leaders enforcing their responsibility and accountability.

The article also develops a pathway for future studies that can advance the research agenda on personalised politics. Follower-centric models expand theories about political cognition conceptually. This common theoretical ground identifies the factors (e.g., leaders' traits and behaviour patterns) that contribute to the attribution of leadership. The effect of this more complex attribution process on voting behaviour, leaders' job approval ratings, and policy preferences also need further research. Follower-centric models assume that citizens do not follow their leaders completely blindly as they have more or less specific expectations about leaders and their leadership. More specifically, leadership prototypes (through prejudices and stereotypes) precede the evaluation of politicians and their policies; however, citizens' impressions and experiences may also influence the latter later on.

Political science can also be benefited from nuancing the process of personalisation by followercentric models. Recent research has shown that people evaluate preferred and non-preferred politicians (de Vries and van Prooijen, 2019) differently, contributing to negative personalisation (Garzia and da Silva, 2021). Partisanship further complicates this picture. While parties can generate different trait associations for their candidates (Hayes, 2005; cf. Maurer et al., 1993), voters are prone to perceive supported politicians as similar to themselves (de Vries and van Prooijen, 2019). This bias also influences the whole attribution process, as the romance of leadership thesis assumes: the supported leader's role is overemphasised in the case of success, while explanations are sought among external factors for failure. In contrast, selective perceptions also work similarly the other way around. Followers are less aware of the achievements of other leaders and magnify their perceived mistakes.

\section{References}

Aarts K, Blais A, Schmitt H, et al. (eds) (2011) Political Leaders and Democratic Elections. Oxford; New York: Oxford University Press.

Achen CH and Bartels LM (2016) Democracy for Realists: Why Elections Do Not Produce Responsive Government. Princeton: Princeton University Press.

Agadjanian A (2020) When Do Partisans Stop Following the Leader? Political Communication 38(4): 351369.

Alabastro A, Rast DE, Lac A, et al. (2013) Intergroup bias and perceived similarity: Effects of successes and failures on support for in- and outgroup political leaders. Group Processes \& Intergroup Relations 16(1): 58-67.

Baker W.D. and Oneal JR (2001) Patriotism or Opinion Leadership?: The Nature and Origins of the 'Rally 'Round the Flag' Effect. The Journal of Conflict Resolution 45(5): 661-687.

Barber B.R. (2000) Neither Leaders Nor Followers: Citizenship Under Strong Democracy. In: Barber B.R. (ed.) A Passion for Democracy: American Essays. Princeton: Princeton University Press, pp.95-110.

Barber M and Pope JC (2019) Does Party Trump Ideology? Disentangling Party and Ideology in America. American Political Science Review 113(1): 38-54.

Barisione M (2009a) So, What Difference Do Leaders Make? Candidates' Images and the "Conditionality" of Leader Effects on Voting. Journal of Elections, Public Opinion and Parties 19(4): 473-500.

Barisione M (2009b) Valence Image and the Standardisation of Democratic Political Leadership. Leadership 5(1): 41-60.

Bennister M, 't Hart P and Worthy B (2017) The Leadership Capital Index: A New Perspective on Political Leadership. Oxford: Oxford University Press.

Bittner A (2011) Platform or Personality?: The Role of Party Leaders in Elections. Oxford; New York: Oxford University Press.

Bligh MC, Kohles JC and Meindl JR (2004) Charisma under crisis: Presidential leadership, rhetoric, and media responses before and after the September 11th terrorist attacks. The Leadership Quarterly 15(2): 211239. 
Bligh MC, Kohles JC and Pillai R (2005) Crisis and Charisma in the California Recall Election. Leadership 1(3): 323-352.

Blondel J (2014) What Have We Learned? In: Rhodes RAW and 't Hart P (eds) The Oxford Handbook of Political Leadership. Oxford; New York : Oxford University Press

Broockman DE and Butler DM (2017) The Causal Effects of Elite Position-Taking on Voter Attitudes: Field Experiments with Elite Communication. American Journal of Political Science 61(1): 208-221.

Brown A (2014) The Myth of the Strong Leader: Political Leadership in Modern Politics. New York: Basic Books.

Burns JM (1978) Leadership. New York: Harper \& Row.

Campbell A, Converse P, Miller W, et al. (1960) The American Voter. Chicago: University of Chicago Press.

Campus D, Switek N and Valbruzzi M (2021) Collective Leadership and Divided Power in West European Parties. Houndmills, Basingstoke, Hampshire: Palgrave Macmillan,

Caprara GV and Zimbardo PG (2004) Personalizing Politics: A Congruency Model of Political Preference. American Psychologist 59(7): 581-594.

Carsten MK, Bligh MC, Kohles JC, et al. (2019) A follower-centric approach to the 2016 U.S. presidential election: Candidate rhetoric and follower attributions of charisma and effectiveness. Leadership 15(2): 179-204.

Christian J, Nayyar D, Riggio R, et al. (2018) Them and us: Did Democrat inclusiveness and Republican solidarity lead to the 2016 U.S. presidential election outcome? Leadership 14(5): 524-542.

de Vries RE and van Prooijen J-W (2019) Voters rating politicians' personality: Evaluative biases and assumed similarity on honesty-humility and openness to experience. Personality and Individual Differences 144: 100-104.

Druckman JN and Levendusky MS (2019) What Do We Measure When We Measure Affective Polarization? Public Opinion Quarterly 83(1): 114-122.

Elgie R (1995) Political Leadership in Liberal Democracies. Houndsmills: Red Globe Press.

Elgie R (2011) Core Executive Studies Two Decades On. Public Administration 89(1): 64-77.

Elgie R (2015) Studying Political Leadership: Foundations and Contending Accounts. Houndmills, Basingstoke, Hampshire: Palgrave Macmillan.

Fiorina M and Shepsle K (1989) Formal Theories of Leadership: Agents, agenda-settters, and entrepreneurs. In: Jones BD (ed.) Leadership and Politics. New Perspectives in Political Science. Lawrence: University Press of Kansas.

Flinders M (2012) Defending Politics: Why Democracy Matters in the Twenty-First Century. Oxford; New York: Oxford University Press.

Foa R.S. and Mounk Y (2016) The Danger of Deconsolidation: The Democratic Disconnect. Journal of Democracy 27(3): 5-17.

Foti RJ, Fraser SL and Lord RG (1982) Effects of leadership labels and prototypes on perceptions of political leaders. Journal of Applied Psychology 67(3): 326-333.

Garzia D (2011) The personalization of politics in Western democracies: Causes and consequences on leaderfollower relationships. The Leadership Quarterly 22(4): 697-709.

Garzia D (2013) Changing Parties, Changing Partisans: The Personalization of Partisan Attachments in Western Europe: Changing Parties, Changing Partisans. Political Psychology 34(1): 67-89.

Garzia D and da Silva FF (2021) Negative personalization and voting behavior in 14 parliamentary democracies, 1961-2018. Electoral Studies Epub ahead of print 17 August. DOI: 10.1016/j.electstud.2021.102300

Garzia D, da Silva FF and de Angelis A (2020) Partisan dealignment and the personalisation of politics in West European parliamentary democracies, 1961-2018. West European Politics: 1-24. Epub ahead of print 17 August DOI: 10.1080/01402382.2020.1845941.

Gherghina S (2021) Party members and leadership styles in new European democracies. The British Journal of Politics and International Relations 23(1): 85-103.

Giessner SR, van Knippenberg D and Sleebos E (2009) License to fail? How leader group prototypicality moderates the effects of leader performance on perceptions of leadership effectiveness. The Leadership Quarterly 20(3): 434-451.

Greene S (2001) The Role of Character Assessments in Presidential Approval. American Politics Research 29(2): 196-210.

Hartley J (2018) Ten propositions about public leadership. International Journal of Public Leadership 14(4): 202-217. 
Haslam SA, Reicher S and Platow M (2020) The New Psychology of Leadership: Identity, Influence and Power. Routledge.

Hayes D (2005) Candidate Qualities through a Partisan Lens: A Theory of Trait Ownership. American Journal of Political Science 49(4). 908-923.

Helms L (2005) Presidents, Prime Ministers, and Chancellors: Executive Leadership in Western Democracies. Houndmills, Basingstoke, Hampshire; New York: Palgrave Macmillan.

Helms L (ed.) (2012) Poor Leadership and Bad Governance: Reassessing Presidents and Prime Ministers in North America, Europe and Japan. Cheltenham; Northampton: Edward Elgar.

Hetherington MJ and Nelson M (2003) Anatomy of a Rally Effect: George W. Bush and the War on Terrorism. P.S.: Political Science and Politics 36(1): 37-42.

Hogg MA, van Knippenberg D and Rast DE (2012) The social identity theory of leadership: Theoretical origins, research findings, and conceptual developments. European Review of Social Psychology 23(1): 258-304.

Howell JM and Shamir B (2005) The Role of Followers in the Charismatic Leadership Process: Relationships and Their Consequences. The Academy of Management Review 30(1): 96-112.

Kane J, Patapan H and 't Hart P (eds) (2009) Dispersed Democratic Leadership: Origins, Dynamics, and Implications. Oxford; New York: Oxford University Press.

Karvonen L (2010) The Personalisation of Politics: A Study of Parliamentary Democracies.

Kellerman B (2008) Followership: How Followers Are Creating Change and Changing Leaders. Boston: Harvard Business School Press.

Kinder DR (1986) Presidential Character Revisited. In: Lau RR and Sears DO (eds) Political Cognition. Hillsdale, NJ: Lawrence Erlbaum.

Kinder DR, Peters MD, Abelson RP, et al. (1980) Presidential Prototypes. Political Behavior 2(4): 315-337.

King A (ed.) (2002) Leaders' Personalities and the Outcomes of Democratic Elections. Oxford: Oxford University Press

Lenz GS (2012) Follow the Leader? How Voters Respond to Politicians' Policies and Performance. Chicago ; London: The University of Chicago Press.

Lobo MC (2014) Party and Electoral Leadership. In: Rhodes RAW and 't Hart P (eds) The Oxford Handbook of Political Leadership,. Oxford; New York: Oxford University Press

Lobo MC and Curtice J (eds) (2015) Personality Politics? The Role of Leader Evaluations in Democratic Elections. Oxford: Oxford University Press.

Lord RG and Maher KJ (1993) Leadership and Information Processing: Linking Perceptions and Performance. London; New York: Routledge.

Lord RG, Epitropaki O, Foti RJ, et al. (2020) Implicit Leadership Theories, Implicit Followership Theories, and Dynamic Processing of Leadership Information. Annual Review of Organizational Psychology and Organizational Behavior 7(1): 49-74.

Maurer TJ, Maher KJ, Ashe DK, et al. (1993) Leadership Perceptions in Relation to a Presidential Vote. Journal of Applied Social Psychology 23(12): 959-979.

McAllister I (2007) The Personalization of Politics. In: Dalton RJ and Klingemann H-D (eds) The Oxford Handbook of Political Behavior. Oxford: Oxford University Press, pp.571-588.

McDonnell D (2016) Populist Leaders and Coterie Charisma. Political Studies 64(3): 719-733.

Medvic SK (2013) In Defense of Politicians: The Expectations Trap and Its Threat to Democracy. New York: Routledge.

Meindl JR (1990) On leadership: An alternative to the conventional wisdom. Research in Organizational Behavior 12: 159-203.

Meindl JR (1995) The romance of leadership as a follower-centric theory: A social constructionist approach. The Leadership Quarterly 6(3): 329-341.

Meindl JR (2004) Romance of leadership. In: Goethals GR, Sorenson GJ, and Burns JM (eds) Encyclopedia of Leadership. Thousand Oaks: Sage Publications, pp.1347-1351.

Meindl JR, Ehrlich SB and Dukerich JM (1985) The Romance of Leadership. Administrative Science Quarterly 30(1): 78-102.

Metz R (2021) Democratic leadership as a political weapon: competition between fictions and practices. International Journal of Public Leadership Epub ahead of print 17 August. DOI: 10.1108/IJPL-092020-0094.

Miller AH, Wattenberg MP and Malanchuk O (1986) Schematic Assessments of Presidential Candidates. American Political Science Review 80(2): 521-540. 
Mueller JE (1970) Presidential Popularity from Truman to Johnson. American Political Science Review 64(1): $18-34$.

Newman B (2003) Integrity and Presidential Approval, 1980-2000. Public Opinion Quarterly 67(3): 335-367. Nye JS (2008) The Powers to Lead. New York; Oxford: Oxford University Press.

Offermann LR and Coats MR (2018) Implicit theories of leadership: Stability and change over two decades. The Leadership Quarterly 29(4): 513-522.

Page BI and Jones CC (1979) Reciprocal Effects of Policy Preferences, Party Loyalties and the Vote. American Political Science Review 73(4): 1071-1089.

Pastor JC, Mayo M and Shamir B (2007) Adding fuel to fire: The impact of followers' arousal on ratings of charisma. Journal of Applied Psychology 92(6): 1584-1596.

Pillai R and Williams EA (1998) Does leadership matter in the political arena? Voter perceptions of candidates' transformational and charismatic leadership and the 1996 U.S. president. The Leadership Quarterly 9(3): 397-416.

Pillai R, Williams EA, Lowe KB, et al. (2003) Personality, transformational leadership, trust, and the 2000 U.S. presidential vote. The Leadership Quarterly 14(2): 161-192

Platow MJ and van Knippenberg D (2001) A Social Identity Analysis of Leadership Endorsement: The Effects of Leader Ingroup Prototypicality and Distributive Intergroup Fairness. Personality and Social Psychology Bulletin 27(11): 1508-1519.

Poguntke T and Webb P (2018) Presidentialization, Personalization and Populism. The Hollowing out of Party Government. In: Cross WP, Katz RS, and Pruysers S (eds) The Personalization of Democratic Politics and the Challenge for Political Parties. London; New York: ECPR Press, pp.181-197.

Rahat G and Sheafer T (2007) The Personalization(s) of Politics: Israel, 1949-2003. Political Communication 24(1): 65-80.

Rahn WM, Aldrich JH, Borgida E, et al. (1990) A Social-Cognitive Model of Candidate Appraisal. In: Ferejohn JA and Kulkinski JH (eds) Information and Democratic Processes. Urbana: University of Illinois Press.

Ross L (1977) The Intuitive Psychologist And His Shortcomings: Distortions in the Attribution Process. In: Berkowitz L (ed.) Advances in Experimental Social Psychology. San Diego: Academic Press, pp.173220.

Shamir B (1992) Attribution of Influence and Charisma to the Leader: The Romance of Leadership Revisited. Journal of Applied Social Psychology 22(5): 386-407.

Shamir B (1994) Ideological Position, Leaders' Charisma, and Voting Preferences: Personal vs. Partisan Elections. Political Behavior 16(2): 265-287.

Shamir B (2009) From Passive Recipients to Active Co-Producers: Followers' Role in the Leadership Process. In: Shamir B, Pillai R, Bligh MC, et al. (eds) Follower-Centered Perspectives on Leadership: A Tribute to the Memory of James R. Meindl. Greenwich: IAP, pp.ix-xxxix.

Skowronek S (1997) The Politics Presidents Make: Leadership from John Adams to Bill Clinton. Cambridge: The Belknap Press of Harvard University Press.

Steffens NK, Haslam SA and Reicher SD (2014) Up close and personal: Evidence that shared social identity is a basis for the 'special' relationship that binds followers to leaders. The Leadership Quarterly 25(2): 296-313.

Sullivan JL, Aldrich JH, Borgida E, et al. (1990) Candidate Appraisal and Human Nature: Man and Superman in the 1984 Election. Political Psychology 11(3): 459-484.

Uhl-Bien M, Riggio RE, Lowe KB, et al. (2014) Followership theory: A review and research agenda. The Leadership Quarterly 25(1). 83-104.

Williams EA, Pillai R, Lowe KB, et al. (2009) Crisis, charisma, values, and voting behavior in the 2004 presidential election. The Leadership Quarterly 20(2): 70-86.

Williams EA, Pillai R, Deptula B, et al. (2012) The effects of crisis, cynicism about change, and value congruence on perceptions of authentic leadership and attributed charisma in the 2008 presidential election. The Leadership Quarterly 23(3): 324-341. 